\title{
Analysis of Mining Damage Notifications in Single-Family Buildings after the Occurrence of Intensive Mining Tremors**
}

\section{Introduction}

Mining damage is caused by changes in ground surface topography due to the movement of the rock mass elements towards the working, by mining tremors, possibly by a change in hydrological conditions in the substrate (e.g. [5]). The damage may occur in building structures in the form of failures, accelerated technical wear and additional nuisance of use (e.g. [4, 13]). In accordance with the applicable provisions of the Polish law [11, 12], the entrepreneur running the mining plant is held responsible for the damage caused by the activities of the mine, as well as has an obligation to remove the damage caused. In practice, however, to assess the extent of the damage and to estimate the value of the loss turns out to be problematic. Valuation of mining damage in a building should be preceded by an analysis of the potential causes of damage and failures. Damage or accelerated wear may in fact be caused by other factors, unrelated to mining [13]. The purpose of such an analysis should therefore be isolating these failures which, in whole or in part, are the result of mining activities and for the removal of which the Mining Plant is held responsible.

The main elements of mining impacts on space development in the Legnica-Głogów Copper District are mining tremors. They occur due to a sudden movement, bursts or cracking of the rock mass layers. The associated release of energy is a threat both to workings in the underground part of the mine, as well as to objects located on the surface, e.g. [2, 7-10]. Occurrence of mining tremors in the area of the Legnica-Głogów Copper District is stimulated by both natural factors as well as technical and operational ones. Deposits of limestone, sandstone and anhydrite, lying over copper ore deposits, have the ability to accumulate elastic energy, releasing it during the burst of the rock mass. A circumstance which is favourable for energy accumulation is also considerable operating at a depth, of 600 to over 1000 meters [10].

\footnotetext{
* AGH University of Science and Technology, Faculty of Mining Surveying and Environmental Engineering, Department of Engineering Surveying and Civil Engineering, Krakow, Poland

** The article was prepared within the scope of the AGH statutory research no. 11.11.150.005
} 
A violent stress relief in the rock layers in the epicenter of the tremor at the hypocentral depth $H$ generates elastic seismic waves that propagate to the surface layer, generating longitudinal and transverse surface waves, propagating over long distances and affecting the housing development in the area (Fig. 1).

They are an additional dynamic load for building structures. The horizontal component of the vibration has a particularly significant impact on the threat to a housing development $[3,6,10]$.

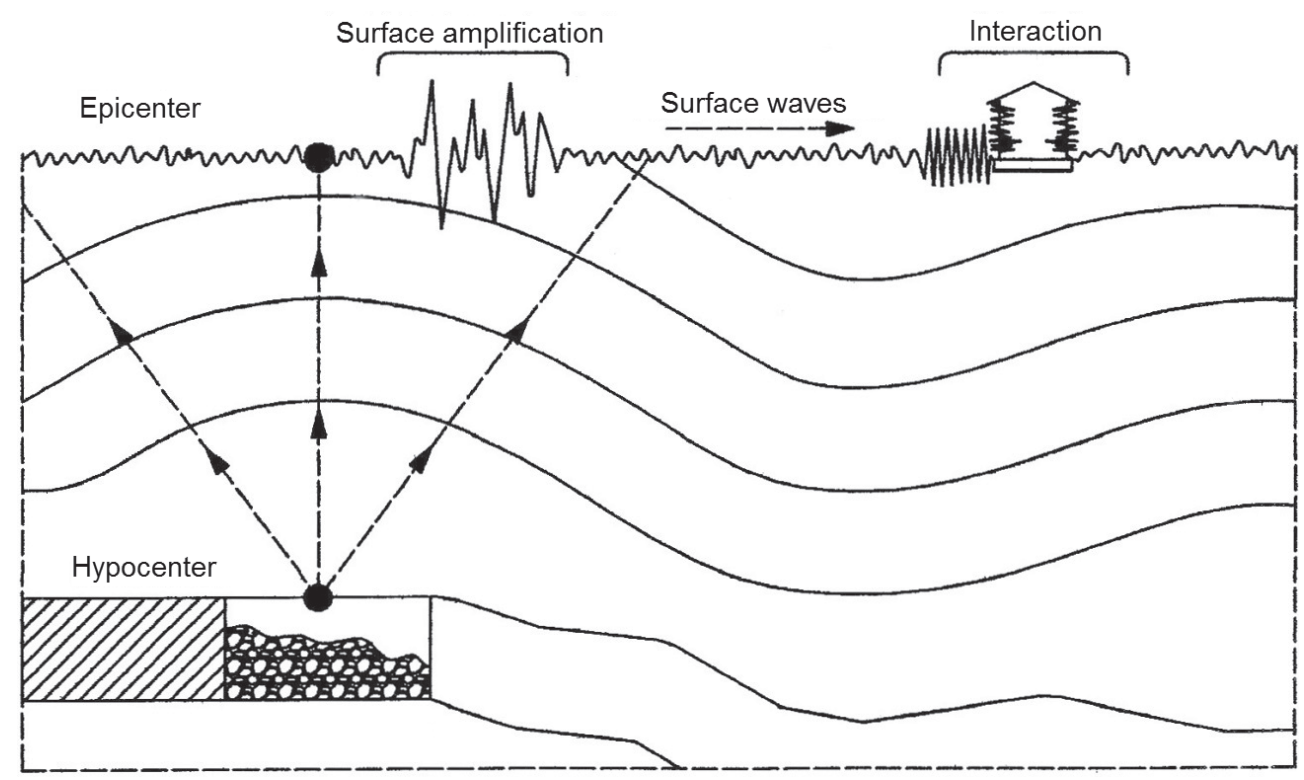

Fig. 1. Propagation of seismic waves in the rock mass

Source: [1]

High-energy tremors, with energies $E \geq 10^{8} \mathrm{~J}$, are considered to be of significant importance in the issues of protection of building structures in mining areas [6].

The article presents an analysis of notifications to recognize mining damage in single-family housing estates in Polkowice after the occurrence of three strongest tremors in that area. This applies to:

- the tremor of 20 February 2002 with the energy of $1.5 \cdot 10^{9} \mathrm{~J}$,

- the tremor of 16 May 2004 with the energy of $84 \cdot 10^{8} \mathrm{~J}$,

- the tremor of 21 May 2006 with the energy of $1.9 \cdot 10^{9} \mathrm{~J}$.

A group of 256 single-family residential buildings were studied, representing the three housing estates in Polkowice, located in the mining area. The construction data of individual buildings were collected during a detailed architectural and constructional inventory, complemented by the analysis of the available design documentation as well as interviews with the owners and users of the real properties. 
The informations about the damage in the buildings reported by the residents, which occurred after each of the analyzed tremors, were obtained at the Mining Plant. The analysis took into account the structural and material characteristics of the buildings, as well as subdivision into damage to structural elements and to secondary elements.

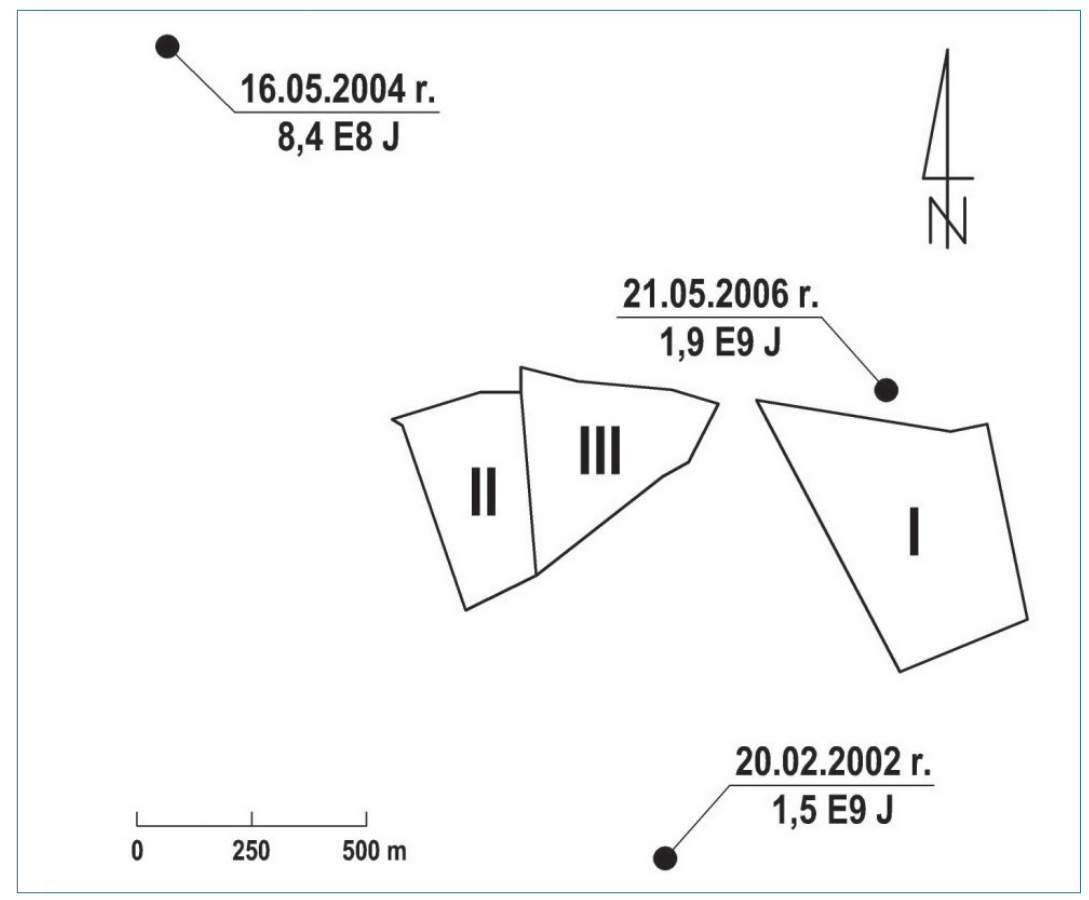

Fig. 2. Location of the epicenters of the analyzed high-energy mining tremors and of the development of the studied housing estates

The location of the epicenters of the analyzed tremors in relation to the development of the studied housing estates has been presented in Figure 2.

\section{Specifications of the Studied Buildings}

The subject of the analysis were single-family residential buildings located on three housing estates in Polkowice, erected after 1980 (Tab. 1).

Considering the scope of the research, the study was limited to the buildings erected before the first of tremors that is before 2002. These buildings are either detached $(30.1 \%)$, semi-detached $(29.7 \%)$ or terraced $(40.2 \%)$. The shapes of the plans and of the buildings took a variety of forms (Tab. 2), but the majority of the buildings had a simple or slightly fragmented plan (70.3\%) and a compact form (55.5\%). 
Table 1. Location of the test stand (256 buildings)

\begin{tabular}{|c|c|c|}
\hline \multirow{2}{*}{ Housing estate } & \multicolumn{2}{|c|}{ Number of buildings } \\
\cline { 2 - 3 } & [items] & {$[\%]$} \\
\hline \hline I & 114 & 44,5 \\
\hline II & 89 & 34,8 \\
\hline III & 53 & 20,7 \\
\hline
\end{tabular}

Table 2. Development type and shape of the plan and building form of the studied building structures

\begin{tabular}{||l|l|c|c||}
\hline \multicolumn{1}{|c|}{ Feature } & \multicolumn{1}{|c|}{ Form } & \multicolumn{2}{c|}{ Number of buildings } \\
\cline { 3 - 4 } & & {$[$ items] } & [\%] \\
\hline \hline \multirow{3}{*}{ Development type } & detached and semi-detached & 153 & 59.8 \\
\cline { 2 - 4 } & terraced & 103 & 40.2 \\
\hline \multirow{3}{*}{ Shape of the plan and building form } & simple or slightly fragmented, elongated & 103 & 40.2 \\
\cline { 2 - 4 } & simple or slightly fragmented, compact & 77 & 30.1 \\
\cline { 2 - 4 } & greatly fragmented, compact & 65 & 25.4 \\
\cline { 2 - 4 } & greatly fragmented, elongated & 11 & 4.3 \\
\hline
\end{tabular}

All the analyzed buildings were situated at a constant level on concrete foundations. Basement and foundation walls were monolithic concrete $(51.6 \%)$ or made with concrete blocks (48.4\%).

Most commonly, envelopes were diaphragm walls with thermal insulation inside, and a masonry layer of the façade made of ceramic bricks from the outside. The load-bearing walls of higher floors were built of cellular concrete $(57.0 \%)$ or slag concrete blocks (43.0\%). Stairs and lintels were generally made of monolithic reinforced concrete.

All the analyzed building structures had basements, under the whole or part of the structure, but always a constant level of foundation was retained.

The studied sample exhibited considerable variation in both basement ceilings and upper floors (Tab. 3). In the case of the buildings erected in the 80s of the twentieth century, the dominant group consists of prefabricated reinforced concrete floors, mainly of hollow core slabs, and ribbed slabs, mostly of DZ-type, prefabricated in whole $(75.1 \%$ and $74.6 \%$, respectively). Later, more popular were monolithic reinforced concrete floor slabs and ribbed, partially prefabricated slabs, most commonly of Teriva or Fert types $(78.7 \%$ and $82.7 \%$, respectively). A characteristic feature of the analyzed objects was diversified levels of ceiling supports within each floor (tie beams shifted by about $1 \mathrm{~m}-62.9 \%$ of the considered buildings). 
Table 3. Structure of the ceilings of basements and higher floors in the analyzed buildings

\begin{tabular}{|c|c|c|c|c|c|c|c|}
\hline \multirow[t]{2}{*}{ Ceilings } & \multirow[t]{2}{*}{ Structure } & \multicolumn{2}{|c|}{$\begin{array}{l}\text { Total number of } \\
\text { buildings }\end{array}$} & \multicolumn{2}{|c|}{$\begin{array}{l}\text { Buildings erected } \\
\text { in the years } \\
\text { 1980-1989 }\end{array}$} & \multicolumn{2}{|c|}{$\begin{array}{l}\text { Buildings erected } \\
\text { in the years } \\
\text { 1990-2001 }\end{array}$} \\
\hline & & [items] & {$[\%]$} & [pcs.] & {$[\%]$} & [items] & {$[\%]$} \\
\hline \multirow[b]{2}{*}{ Basement } & prefabricated slabs & 152 & 59.4 & 136 & 75.1 & 16 & 21.3 \\
\hline & $\begin{array}{l}\text { monolithic reinforced } \\
\text { concrete }\end{array}$ & 104 & 40.6 & 45 & 24.9 & 59 & 78.7 \\
\hline \multirow[b]{2}{*}{ Higher floors } & prefabricated slabs & 148 & 57.8 & 135 & 74.6 & 13 & 17.3 \\
\hline & $\begin{array}{l}\text { monolithic reinforced } \\
\text { concrete }\end{array}$ & 108 & 42.2 & 46 & 25.4 & 62 & 82.7 \\
\hline
\end{tabular}

The building systems of the 1980s most frequently used bipartite ventilated flat roofs with roofing of prefabricated hollow core roof plates based on openwork walls and covered with roofing paper. The buildings erected in the 90s of the twentieth century, and later, mostly had steep roofs with wooden rafter framing and were covered with steel sheet or ceramic tiles.

In the study group, the vast majority, i.e. 202 buildings (78.9\%), had no protection against mining tremors. The other 54 objects were issued with a decision or planning permission by the District Mining Office, taking into account mining impacts on the planned investment. They specified, inter alia, the predicted maximum horizontal acceleration or velocity of the vibration on the surface, but only one building had a documented protection against tremors in the form of concrete studs.

\section{Structure of Mining Damage Notifications}

Damage reported by the residents was divided into two groups: regarding the structural and non-structural elements (in individual cases, the notifications also concerned furnishings that were omitted in the analysis). The set of structural components included foundations, load-bearing walls (foundation, basement, overground), lintels, walls (under the windows, firewalls), ceilings, roofs, roof structures, balconies and loggias. The secondary, non-structural elements included partition walls, internal plasters, façade layers, wall cladding, floors, damp proof insulation, roofing, flashings, gutters and downspouts, entrances to the buildings, windows, doors and installations.

The structure of the mining damage notifications after the above-mentioned tremors have been presented in Table 4, and their classification by the Mining Plant has been depicted in Table 5 . 
Table 4. Structure of mining damage notifications in the analyzed buildings after high-intensity tremors

\begin{tabular}{|c|c|c|c|c|c|c||}
\hline \multirow{2}{*}{$\begin{array}{c}\text { Date } \\
\text { of the tremor }\end{array}$} & \multicolumn{2}{|c|}{$\begin{array}{c}\text { Number } \\
\text { of notifications }\end{array}$} & \multicolumn{2}{c|}{$\begin{array}{c}\text { Notification } \\
\text { of damage to } \\
\text { structural elements }\end{array}$} & \multicolumn{2}{c||}{$\begin{array}{c}\text { Notification } \\
\text { of damage to } \\
\text { secondary elements }\end{array}$} \\
\cline { 2 - 7 } & [items] & {$[\%]$} & [items] & {$[\%]$} & [items] & [\%] \\
\hline \hline 20.02 .2002 & 73 & 28.5 & 65 & 25.4 & 70 & 27.3 \\
\hline 16.05 .2004 & 13 & 5.1 & 11 & 4.3 & 11 & 4.3 \\
\hline 21.05 .2006 & 55 & 21.5 & 48 & 18.8 & 47 & 18.4 \\
\hline
\end{tabular}

Table 5. Structure of qualifying mining damage notifications by the Mining Plant

\begin{tabular}{|c|c|c|c|c|c|c|c|}
\hline \multirow{3}{*}{$\begin{array}{l}\text { Date } \\
\text { of the tremor }\end{array}$} & \multirow{3}{*}{$\begin{array}{c}\begin{array}{c}\text { Number } \\
\text { of notifications }\end{array} \\
\text { [items] }\end{array}$} & \multicolumn{6}{|c|}{ Qualification of the notification } \\
\hline & & \multicolumn{2}{|c|}{ accepted } & \multicolumn{2}{|c|}{ rejected } & \multicolumn{2}{|c|}{$\begin{array}{l}\text { qualified } \\
\text { for further } \\
\text { observation }\end{array}$} \\
\hline & & [items] & {$[\%]$} & [items] & {$[\%]$} & [items] & {$[\%]$} \\
\hline 20.02 .2002 & 73 & 64 & 87.7 & 5 & 6.8 & 4 & 5.5 \\
\hline 16.05 .2004 & 13 & 7 & 53.8 & 3 & 23.1 & 3 & 23.1 \\
\hline 21.05 .2006 & 55 & 39 & 70.9 & 15 & 27.3 & 1 & 1.8 \\
\hline
\end{tabular}

The presented data depicts that most notifications (73 cases) were submitted after the first high-energy tremor on 20 February 2002. As a result of the on-site inspections carried out by the staff of the Department of Mining Damage of the Mining Plant "Rudna" in the reported buildings, the majority of notifications (64 cases, or $87.7 \%$ ) were recognized as valid. Therefor, the mine paid the owners one-off damages for the resulting losses or ordered reparation of the recognized damage by restoring the buildings to their original condition. The subject of the notifications submitted by the owners were mostly cracks and scratches occurring both on structural elements (load-bearing walls, ceilings) as well as on secondary elements (partition walls, wall and floor cladding, entrance to buildings).

As a result of the tremor on 16 May 2004, the Mining Plant had a much smaller number of reported damage to these buildings (13 notifications). This was probably due to the effectiveness of the repair and safety works carried out after the previously analyzed tremor. This thesis can be substantiated by the fact that the owners of 57 buildings (which is more than $89.0 \%$ ), who in February 2002 reported the mining damage, which was then confirmed, did not submit the notification again in 2004. As a result of the on-site inspections conducted in the reported buildings, about half of the notifications $(53.8 \%)$ were accepted. 
The strongest tremor in Polkowice in the analyzed period occurred on 21 May 2006 , with the energy of $1.9 \cdot 10^{9} \mathrm{~J}$. As a result, the number of applications for compensation for mining damage increased again (55 cases). As in previous years, the majority of them $(70.9 \%)$ were found to be justified, which resulted in a one-off payment of damages or repair of the resulting damage.

Due to the limited number of notifications after the tremor of 16 May 2004, further research examined the effects of the two high-energy tremors, of 20 February 2002 and of 21 May 2006.

\section{Structure of Mining Damage Notifications and Technical Features of the Buildings}

The studied buildings are either detached, semi-detached, or terraced. Shapes of the plans and building forms vary (c.f. Tab. 2), but predominantly these are objects characterized by a simple or slightly fragmented plan and compact form. Therefore, the structure of the damage notifications after the tremors was examined, depending on the type of a development, the shape of the plan and the shape of the building form. Pearson's chi-square test of independence was used, based on a comparison of the observed values with the hypothetical ones for categorical (qualitative) variables. The level of significance was adopted at $p=0.05$. The obtained results have been presented in Table 6.

Table 6. Levels of statistical significance of Pearson's chi-square test obtained during the study of a relationship between development features and the structure of notifications after the tremors in 2002 and 2006

\begin{tabular}{||l|c|c||}
\hline \multirow{2}{*}{ Development features } & $\begin{array}{c}\text { Notification of damage } \\
\text { to structural elements }\end{array}$ & $\begin{array}{c}\text { Notification of damage } \\
\text { to secondary elements }\end{array}$ \\
\cline { 2 - 3 } & $p$ & $p$ \\
\hline \hline Type of development & 0.00033 & 0.00063 \\
\hline $\begin{array}{l}\text { Shape of the plan and } \\
\text { building form }\end{array}$ & 0.00000 & 0.00017 \\
\hline
\end{tabular}

The above data proves that there are significant, in statistical terms, relationships between the structure of the damage reported by the owners, and both of the studied development features.

Table 7 illustrates the reported damage in percentage, and their qualification by the Mining Plant, depending on the category of the studied feature in a given group of buildings. 
Table 7. Percentage of damage in a given group of reported buildings and its qualification by the Mining Plant, depending on the development features

\begin{tabular}{|c|c|c|c|c|c|c|}
\hline \multirow{3}{*}{\multicolumn{2}{|c|}{ Development features }} & \multicolumn{2}{|c|}{$\begin{array}{l}\text { Percentage of damage in a given } \\
\text { group of reported buildings, with } \\
\text { damage to: }\end{array}$} & \multicolumn{3}{|c|}{$\begin{array}{l}\text { Qualification of the damage } \\
\text { in the reported buildings } \\
\text { by the Mining Plant }\end{array}$} \\
\hline & & $\begin{array}{c}\text { structural } \\
\text { elements }\end{array}$ & $\begin{array}{l}\text { secondary } \\
\text { elements }\end{array}$ & $\begin{array}{l}\text { structural } \\
\text { elements }\end{array}$ & $\begin{array}{l}\text { secondary } \\
\text { elements }\end{array}$ & $\begin{array}{l}\text { structural } \\
\text { elements }\end{array}$ \\
\hline & & {$[\%]$} & [\%] & {$[\%]$} & [\%] & [\%] \\
\hline \multirow{2}{*}{ 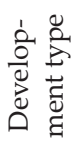 } & terraced & 30.1 & 30.6 & 82.6 & 13.0 & 4.4 \\
\hline & $\begin{array}{l}\text { detached and } \\
\text { semi-detached }\end{array}$ & 16.7 & 17.6 & 78.0 & 18.6 & 3.4 \\
\hline \multirow{4}{*}{ 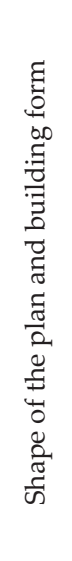 } & $\begin{array}{l}\text { greatly } \\
\text { fragmented, } \\
\text { elongated }\end{array}$ & 40.9 & 50.0 & 84.6 & 15.4 & 0.0 \\
\hline & $\begin{array}{l}\text { simple or slightly } \\
\text { fragmented, } \\
\text { elongated }\end{array}$ & 27.7 & 28.6 & 84.1 & 9.5 & 6.4 \\
\hline & $\begin{array}{l}\text { greatly } \\
\text { fragmented, } \\
\text { compact }\end{array}$ & 17.7 & 18.5 & 76.9 & 23.1 & 0.0 \\
\hline & $\begin{array}{l}\text { simple or slightly } \\
\text { fragmented, } \\
\text { compact }\end{array}$ & 13.0 & 14.9 & 73.1 & 23.1 & 3.8 \\
\hline
\end{tabular}

These data show that the percentage of submitted applications for payment of damages was nearly twice as high for terraced houses than for detached and semi-detached ones. This trend is common both for the reported damage to structural elements and to secondary elements.

While analyzing the development of the housing estates with respect to the shape of the plan and building form, it can be noticed that the overwhelming number of submitted notifications regarded greatly fragmented buildings with elongated shapes. The percentage of reported notifications (both regarding the damage to structural and secondary elements) was more than three times higher than for the buildings with a simple or slightly fragmented plan and compact shape.

Among all the analyzed cases, about $75-80 \%$ of notifications were considered justified by the Mining Plant, confirming the occurrence of damage caused by mining activities. 


\section{Structure of Mining Damage Notifications and Design Features of the Buildings}

The structure of the damage reported after the tremors was also examined, depending on the structural and material solutions used in the buildings. Damage to both secondary and structural elements was identified.

Again, Pearson's chi-square test of independence was used, with the level of significance adopted at $p=0.05$. The obtained results have been presented in Table 8 .

Table 8. Levels of statistical significance of Pearson's chi-square test obtained during the study of a relationship between design features of the buildings and the structure of the notifications after the tremors in 2002 and 2006

\begin{tabular}{|c|c|c|c|}
\hline \multirow{2}{*}{\multicolumn{2}{|c|}{ Elements of the building }} & $\begin{array}{l}\text { Notification of damage } \\
\text { to structural elements }\end{array}$ & $\begin{array}{c}\text { Notification of } \\
\text { damage to secondary } \\
\text { elements }\end{array}$ \\
\hline & & $p$ & $p$ \\
\hline \multicolumn{2}{|c|}{ Foundation and basement walls } & 0.42587 & 0.43932 \\
\hline \multicolumn{2}{|c|}{ Load-bearing walls of higher floors } & 0.03971 & 0.01653 \\
\hline \multicolumn{2}{|l|}{ Basement ceilings } & 0.81241 & 0.58749 \\
\hline \multirow{2}{*}{$\begin{array}{l}\text { Ceilings of higher } \\
\text { floors }\end{array}$} & structure & 0.71828 & 0.35283 \\
\hline & varied levels of support & 0.01587 & 0.04017 \\
\hline
\end{tabular}

A statistically significant relationship was observed between the adopted structural and material solutions of the load-bearing walls of higher floors and the occurrence of varied levels of ceilings, and notifications of damage to both load-bearing elements and non-structural elements. In other cases, there was no significant correlation between the variables observed.

Table 9 illustrates the reported damage in percentage, and its qualification by the Mining Plant, depending on the cases, significant in the statistical sense.

These data show that the percentage of damage to the structural and secondary elements in the buildings with walls made of cellular concrete is about $50 \%$ higher compared to the buildings with the walls made of slag concrete blocks. 
Table 9. Percentage of damage in a given group of reported buildings and its qualification by the Mining Plant, depending on the structure of the building elements

\begin{tabular}{|c|c|c|c|c|c|c|c|}
\hline \multirow{3}{*}{\multicolumn{3}{|c|}{$\begin{array}{l}\text { Elements } \\
\text { of the building }\end{array}$}} & \multicolumn{2}{|c|}{$\begin{array}{c}\text { Percentage of damage } \\
\text { in a given group of reported } \\
\text { buildings, } \\
\text { with damage to: }\end{array}$} & \multicolumn{3}{|c|}{$\begin{array}{l}\text { Qualification of the damage } \\
\text { in the reported buildings } \\
\text { by the Mining Plant }\end{array}$} \\
\hline & & & $\begin{array}{l}\text { structural } \\
\text { elements }\end{array}$ & $\begin{array}{l}\text { secondary } \\
\text { elements }\end{array}$ & accepted & rejected & $\begin{array}{l}\text { qualified } \\
\text { for further } \\
\text { observation }\end{array}$ \\
\hline & & & [\%] & [\%] & {$[\%]$} & [\%] & {$[\%]$} \\
\hline \multirow{2}{*}{\multicolumn{2}{|c|}{$\begin{array}{l}\text { Walls of } \\
\text { higher } \\
\text { floors }\end{array}$}} & $\begin{array}{l}\text { of cellular } \\
\text { concrete }\end{array}$ & 25.3 & 26.7 & 81.2 & 14.1 & 4.7 \\
\hline & & $\begin{array}{l}\text { of slag concrete } \\
\text { blocks }\end{array}$ & 17.7 & 17.7 & 79.1 & 18.6 & 2.3 \\
\hline \multirow{4}{*}{ 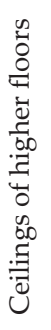 } & \multirow{2}{*}{ 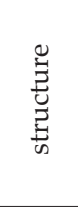 } & $\begin{array}{c}\text { prefabricated } \\
\text { slabs }\end{array}$ & 22.6 & 24.3 & 83.3 & 10.3 & 6.4 \\
\hline & & $\begin{array}{l}\text { monolithic } \\
\text { reinforced } \\
\text { concrete }\end{array}$ & 21.3 & 20.8 & 76.0 & 24.0 & 0.0 \\
\hline & \multirow{2}{*}{ 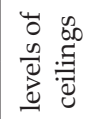 } & shifted & 25.5 & 25.8 & 83.3 & 12.2 & 4.4 \\
\hline & & fixed & 16.3 & 17.9 & 73.7 & 23.7 & 2.6 \\
\hline
\end{tabular}

While analyzing the effect of varying height of ceiling supports, it is apparent that about $50 \%$ greater number of notifications (both referring to structural and non-structural elements) were submitted in the case of varied levels of the ceilings. As it was in the case of the development features analyzed in Chapter 4, about $75-80 \%$ of the notifications were considered justified by the Mining Plant.

\section{Summary}

The article analyzes the notifications of mining damage to buildings in single-family housing estates in Polkowice. The damage occurred after three high-energy mining tremors on 20 February 2002, 16 May 2004, and 21 May 2006. The study group was comprised of 256 houses built in the traditional brick technology between 1980 and 2002. The paper attempted to find a relationship between the structure of mining damage reported after the tremors and the development and design features of the buildings.

The obtained results proved the existence of statistically significant relationships between damage to both structural and secondary elements, as well as the type of development and geometry of the buildings (Chapter 4). 
A significant effect of the applied structural and material solutions in load-bearing walls of the higher floors, as well as varied levels of ceiling supports on the scope of the damage, has been identified as well (Chapter 5).

These results confirm the necessity of applying structural and material solutions which would ensure to buildings exposed to mining tremors the appropriate spatial rigidity and, consequently, resistance to dynamic loads.

\section{References}

[1] Ciesielski R.: O drganiach powierzchni gruntu na skutek wstrzasów górniczych. [in:] Wptywy sejsmiczne i parasejsmiczne na budowle: IX Sympozjum: materiaty z Sympozjum Naukowego zorganizowanego przez Instytut Mechaniki Budowli Politechniki Krakowskiej, Politechnika Krakowska, Kraków 2000, pp. 215-222.

[2] Dubiński J., Mutke G.: Weryfikacja skali GSI-2004 oceny skutków drgań wywołanych wstrzasami górniczymi w obszarze LGOM. [in:] Materiały Sympozjum Warsztaty Górnicze z cyklu Zagrożenia naturalne w górnictwie: sesja okolicznościowa Rozwiazania inżynierskie $i$ badania naukowe dla ograniczania zagrożeń naturalnych w górnictwie, Kraków-Tomaszowice, 12-14 czerwca 2006, IGSMiE PAN, Kraków 2006, pp. 79-93.

[3] Firek K.: Badanie wptywu czynników górniczych i budowlanych na zużycie techniczne tradycyjnej zabudowy terenu górniczego LGOM. Akademia Górniczo-Hutnicza, Wydział Geodezji Górniczej i Inżynierii Środowiska, Kraków 2005 [Ph.D. thesis].

[4] Kawulok M.: Szkody górnicze w budownictwie. Instytut Techniki Budowlanej, Warszawa 2010.

[5] Kwiatek J.: Podstawy budownictwa na terenach górniczych. Uczelniane Wydawnictwa Naukowo-Dydaktyczne AGH, Kraków 2004.

[6] Kwiatek J.: Obiekty budowlane na terenach górniczych. Główny Instytut Górnictwa, Katowice 2007.

[7] Minch M.Y., Samokar Z.: Analiza skutków dużego wstrzasu górniczego na zabudowę powierzchniowa miasta Polkowice. [in:] Awarie budowlane: zapobieganie, diagnostyka, naprawy, rekonstrukcje: XXIII konferencja naukowo-techniczna, Szczecin-Międzyzdroje, 23-26 maja 2007, Wydawnictwo Uczelniane Politechniki Szczecińskiej, Szczecin 2007, pp. 299-306.

[8] Speczik S., Śniegowski I., Samokar Z., Jędrzejec M.: Skutki wystapienia największego wstrzasu górniczego w wysokich budynkach w filarze ochronnym miasta Polkowice. [in:] Materiaty Sympozjum Warsztaty Górnicze z cyklu Zagrożenia naturalne w górnictwie: sesja okolicznościowa Problematyka zagrożeń naturalnych w górnictwie weegla brunatnego, Bełchatów, 2-4 czerwca 2004, IGSMiE PAN, Kraków 2004, pp. 419-432. 
[9] Stolecki L.: Dynamiczne oddziaływania drgań na powierzchnię terenu ZG „Rudna" po wstrzassie z dnia 21.05.2006 roku o energii 1,9· $E^{9} \mathrm{~J}$. [in:] Materiały konferencji naukowej Warsztaty Górnicze z cyklu Zagrożenia naturalne w górnictwie, Ślesin k. Konina, 4-6 czerwca 2007, IGSMiE PAN, Kraków 2007, pp. 299-306.

[10] Tatara T.: Działanie drgań powierzchniowych wywołanych wstrzasami górniczymi na niska zabudowę mieszkalna. Zeszyt Naukowy - Politechnika Krakowska. Inżynieria Lądowa 74, Wyd. Politechniki Krakowskiej, Kraków 2002.

[11] Ustawa z dnia 23 kwietnia 1964 r. Kodeks cywilny. Dz.U. 1964, nr 16, poz. 93 z późn. zm. [Journal of Laws 1964, no. 16, item 93 with amendments].

[12] Ustawa z dnia 9 czerwca 2011 r. Prawo geologiczne i górnicze. Dz.U. 2011, nr 163, poz. 981 z późn. zm. [Journal of Laws 2011, no. 163, item 981 with amendments].

[13] Wodyński A.: Zużycie techniczne budynków na terenach górniczych. Uczelniane Wydawnictwa Naukowo-Dydaktyczne AGH, Kraków 2007. 